\title{
ENDOSCOPIC CHANGES IN THE GASTRIC STUMP MUCOSA AFTER SURGICAL TREATMENT FOR ULCER DISEASE
}

\author{
Biljana Radovanović-Dinić1,2, Snežana Tešić-Rajković1,2
}

\begin{abstract}
Surgical treatment is today restricted mostly to the patients with ulcer disease complications or the small portion of patients with ulcers refractory to conventional therapy. Gastric 'two-thirds' resection is one of the surgical interventions in surgical treatment of ulcer disease. Our prospective study involved 67 patients with two-thirds gastric resection and reconstruction by Billroth I or Billroth II method. In all the examinees, proximal endoscopy was performed. During the endoscopy, esophagus, gastric stump, anastomosis and afferent limbs were observed. There were more males in the group of patients with Billroth I resection $\left(\chi^{2}=\right.$ $1.90 ; p=0.1676)$. The average age of all the examinees was $64.27 \pm 10.07$ years. In 39 patients $(58.21 \%)$, the resection was performed for gastric ulcer or its complications, and in 28 patients $(41.79 \%)$ for ulcer at the duodenal bulb or its complications $\left(\chi^{2}=8.75 ; p=0.0678\right)$. In patients with ulcer of the stomach, Billroth II resection was statistically significantly ( $p<$ 0.05 ) more commonly performed. The average time from resection to endoscopy was slightly longer in those with Billroth I resection ( $p$ value being close to the 0.05 significance cut-off value). Duodenogastric reflux was more commonly encountered in patients with Billroth II gastric resection. Ulceration in the gastric stump was present in 7 (10.44\%) examinees. Carcinoma was found in 2 patients $(2.98 \%)$ in gastric stump, and in 3 patients $(4.95 \%)$ at the anastomosis site. Although in our clinical practice it is increasingly rare to encounter the patients with resected stomach, we should not overlook the possibility of damage to the remnant of the stomach.
\end{abstract}

Acta Medica Medianae 2018;57(4):101-109.

Key words: gastric stump, endoscopy, peptic ulcer

${ }^{1}$ University of Niš, Faculty of Medicine, Niš, Serbia

${ }^{2}$ Clinical Centre Niš, Clinic for Gastroenterology and Hepatology, Niš, Serbia

Contact: Biljana Radovanović-Dinić Elektronska 1/1, $18000 \mathrm{Niš,} \mathrm{Serbia}$ E-mail: bikius@yahoo.com

\section{Introduction}

Peptic ulcer disease is a defect in gastrointestinal mucosa as the result of inability of epithelial cells to resist the caustic action of $\mathrm{HCl}$ and pepsin present in the organ lumen. By their localization, ulcers can be divided into duodenal, distal gastric (antrum, prepyloric region), proximal gastric (angular portion, most of the corpus), and cardial ulcers (cardia and immediate subcardial portion) $(1,2)$.

Ulcer disease is always confirmed morphologically, nowadays most commonly endoscopically. For more than a century, surgery played the most prominent role in the treatment of ulcer disease and its complications. Based on new insights in the field, discovery of powerful antisecretory drugs, significant advances in endoscopic diagnosis and hemostasis, discovery of the role of Helicobacter infection in the pathogenesis of ulcer, the use of surgery is significantly reduced and modified. Surgical treatment is today restricted mostly to the patients with ulcer disease complications or the small portion of patients with ulcers refractory to conventional therapy (3).

Gastric resection is one of the surgical interventions in surgical pathology of the stomach. Resections can be elective (planned) or emergency surgical interventions (ulcer bleeding or perforation). Gastric 'two thirds' resection (subtotal gastrectomy) involves ulcer removal together with gastrin-producing portion of the stomach and most of the body of the stomach with parietal cells. After resection of the part of the stomach, the organ is reconstructed by the methods Billroth I or Billroth II, i.e. by their modifications $(4,5)$.

A postresection gastric stump undergoes not only some significant anatomical-physiological changes, but in the new situation the conditions are created for the stomach remnant to be affected by certain diseases as well. Removal of the antropyloric portion of the stomach reduces its motor function. 
Gastrin cells are located in the antrum and their removal disturbes the endocrine stimulation of gastric secretion; moreover, physiological trophic impact of gastrin on the gastrointestinal mucosa will be absent concomitantly. Removal of a part of the body of the stomach involves the removal of a part of parietal cells, and this will be an additional component in the reduced secretory function of the stomach. By way of the afferent limb, duodenal biliopancreatic juice comes into contact with the gastric stump and splashing the gastric mucosa creates a nonphysiological medium in which harmful effects of bile salts on gastric mucosa become evident. In such conditions, gastric mucosa of the gastric stump suffers significant dystrophic-inflammatory-metaplastic changes, representing in fact a precancerosis $(2,4)$.

The aim of our study was to assess endoscopic changes in the gastric stump after gastric resection undertaken as the therapy of ulcer disease or its complications.

\section{Material and methods}

Our prospective study involved 67 patients with two-thirds gastric resection and reconstruction by Billroth I or Billroth II method. Indications for the resection were recurrent ulcer disease, duodenal perforations and bleeding gastric ulcers.

In all the examinees, proximal endoscopy was performed using an Olympus or Pentax esophagogastroduodenoscope (EGDS). The examination was indicated for the symptoms of dyspepsia or as a regular control after gastric resection. During the endoscopy, esophagus, gastric stump, anastomosis and afferent limbs were observed. From each of the examinees biopsy samples were taken from the gastric stump mucosa, mucosa tissue $1-3 \mathrm{~cm}$ away from the anastomosis, and from all endoscopically suspicious sites. All the biopsy samples were histopathologically analyzed after adequate processing.

Statistical analysis of data was performed using R 2.15.3 software (R Foundation for Statistical Computing, Vienna, Austria) (6).

\section{Results}

Sixty seven patients were enrolled to the study with two-thirds gastric resection; there were 24 patients (35.82\%) with Billroth I gastric reconstruction (Figure 1) and $43(62.18 \%)$ with Billroth II gastric reconstruction (Figure 2 ).

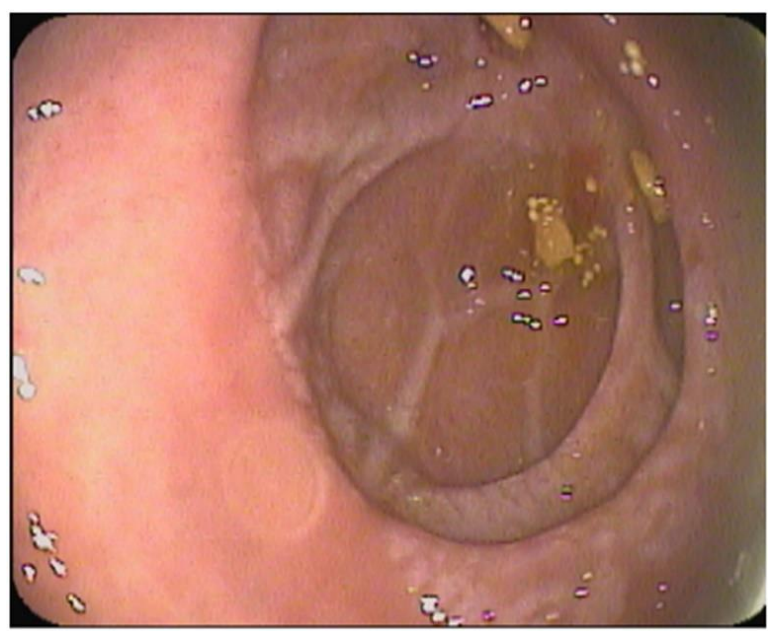

Figure 1. Two-thirds gastric resection with gastroduodenostomy (Billroth I)

There were more males (although not statistically significantly) in the group of patients with Billroth $I$ resection $\left(\chi^{2}=1.90 ; p=0.1676\right)$. The average age of all the examinees was $64.27 \pm 10.07$ years. Using the Student's t-test, we were not able to establish any statistically significant difference in the mean age between the patients surgically treated by Billroth I $(66.42 \pm 8.61)$ and those treated by Billroth II resection $(63.07 \pm 10.70)(\mathrm{t}=1.31 \mathrm{p}=$ $0.1942)$. In 39 patients (58.21\%) the resection was performed for gastric ulcer or its complications, and

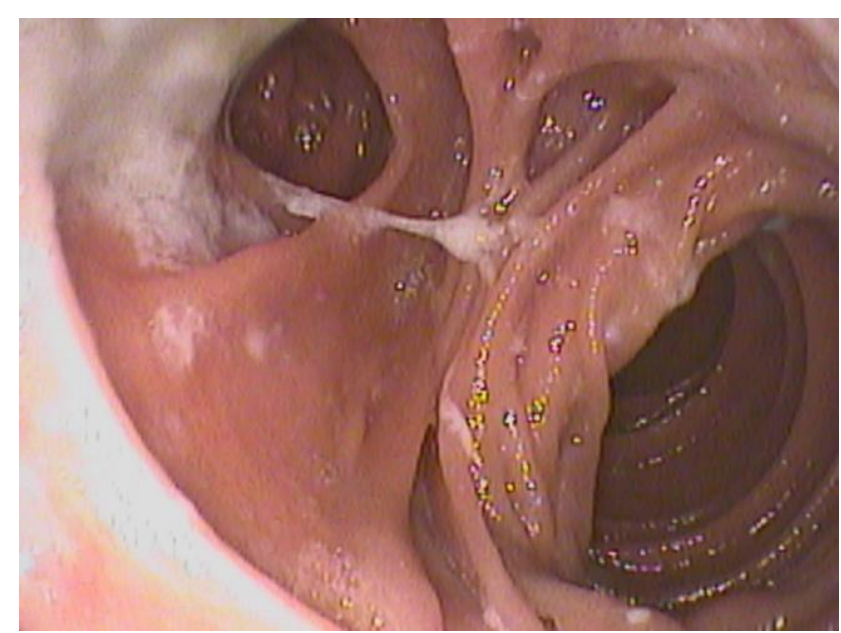

Figure 2. Two-thirds gastric resection with gastrojejunostomy (Billroth II)

in 28 patients $(41.79 \%)$ for ulcer at the duodenal bulb or its complications $\left(\chi^{2}=8.75 ; p=0.0678\right)$. In patients with ulcer of the stomach, Billroth II resection was statistically significantly $(p<0.05)$ more commonly performed, in contrast to those with ulcers at the duodenal bulb in whom both surgical resections were equally common (Table 1 ).

We could not establish a statistically significant difference in the period of time from resection to endoscopy between Billroth I patients (22.67 \pm 9.27) and Billroth II patients (14.22 \pm 11.48) $(\mathrm{t}=$ 
$1.91 \mathrm{p}=0.0675)$. However, the average time from resection to endoscopy was slightly longer in those with Billroth I resection ( $p$ value being close to the 0.05 significance cut-off value) (Table 2). Graph 1 presents an endoscopic finding verified on a gastric stump. Duodenogastric reflux was more commonly encountered in patients with Billroth II gastric resection $\left(\chi^{2}=8.75 ; p=0.0678\right)$ (Figure 3 ). Duodenogastric reflux was more commonly seen in patients with longer postoperative period (Table 3).

Table 1. Demographic characteristics of patients with gastric resection

\begin{tabular}{|l||c|c|c|c||}
\hline \multicolumn{1}{|c|}{ Characteristics } & N = 67 & Billroth I & Billroth II & p-value \\
\hline \hline Gender(male/female) & $43 / 24$ & $18 / 6$ & $25 / 18$ & \\
age (years) & $64.27 \pm 10.07$ & $66.42 \pm 8.61$ & $63.07 \pm 10.70$ & 0.1676 \\
gastric ulcer & $39(58.21 \%)$ & $10(25.64 \%)$ & $29(74.36 \%)$ & 0.1942 \\
duodenal ulcer & $28(41.79 \%)$ & $14(50.00 \%)$ & $14(50.00 \%)$ & \\
\hline
\end{tabular}

Table 2. Period of time from resection to endoscopy (in years)

\begin{tabular}{|l||ccccccccc||}
\hline Groups & $\mathbf{N}$ & $\mathbf{X}$ & SD & SG & $\mathbf{9 5 \%}$ & $\mathbf{C I}$ & Min. & Max. & CV \\
\hline \hline Billroth I & 24 & 22.67 & 9.27 & 3.09 & 15.54 & 29.80 & 11 & 43 & 40.91 \\
BillrothII & 43 & 14.22 & 11.48 & 2.71 & 8.52 & 19.93 & 1 & 38 & 80.69 \\
\hline Total & 67 & 17.04 & 11.36 & 2.19 & 12.54 & 21.53 & 1 & 43 & 66.68 \\
\hline
\end{tabular}

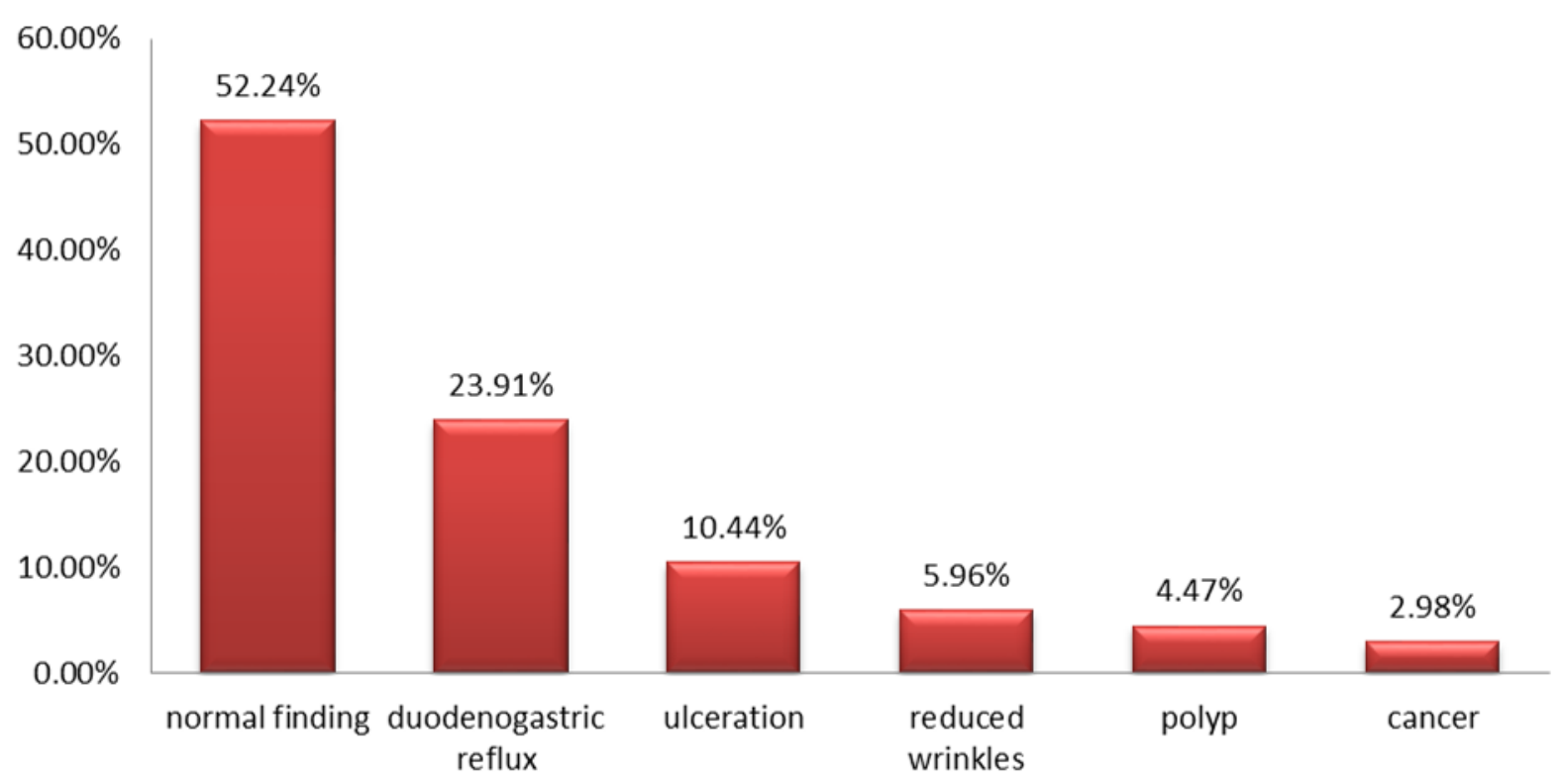

Graph 1. Endoscopic findings in the gastric stump 


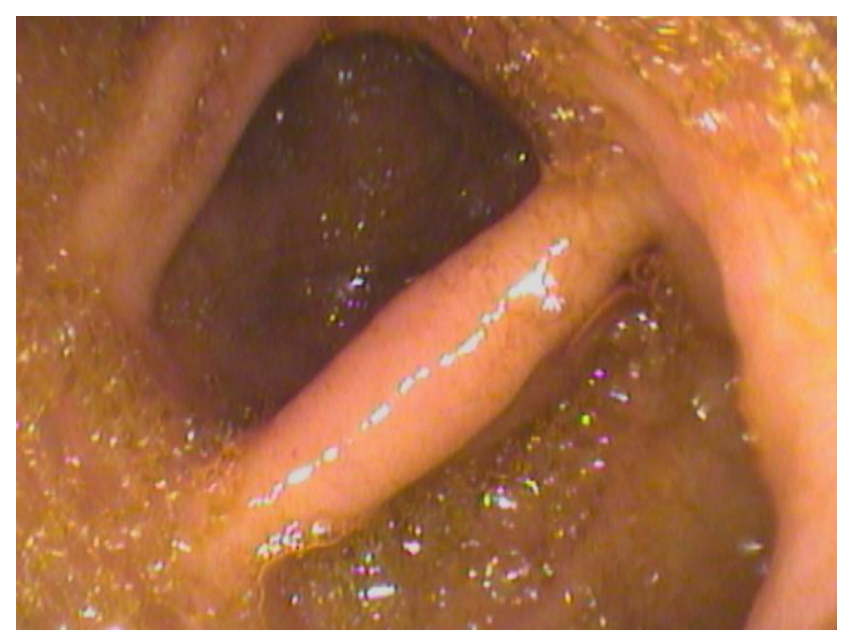

Figure 3. Duodenogastric reflux in the gastric stump after Billroth II resection

Table 3. Postoperative period (years) and presence of duodenogastrix reflux in the gastric stump

\begin{tabular}{||c||c|c|c|c|c|c|c|c|c||}
\hline $\begin{array}{c}\text { Biliogastric } \\
\text { reflux }\end{array}$ & $\mathbf{N}$ & $\mathbf{X}$ & $\mathbf{S D}$ & $\mathbf{S E}$ & $\mathbf{9 5 \%}$ & $\mathbf{C I}$ & Min & Max & CV \\
\hline \hline Yes & 15 & 18.55 & 10.03 & 2.14 & 14.10 & 22.99 & 2 & 43 & 54.07 \\
\hline No & 52 & 10.40 & 15.60 & 6.98 & -8.97 & 29.77 & 1 & 38 & \\
\hline \hline Total & 67 & 17.04 & 11.36 & 2.19 & 12.54 & 21.53 & 1 & 43 & 66.68 \\
\hline
\end{tabular}

Ulceration in the gastric stump was present in $7(10.44 \%)$ examinees (Figure 4$)$. The period of time from resection to confirmed ulcerations was 10.4 years. In 4 (57.14\%) examinees, ulcerations appeared within 2 years after their resections. Car-

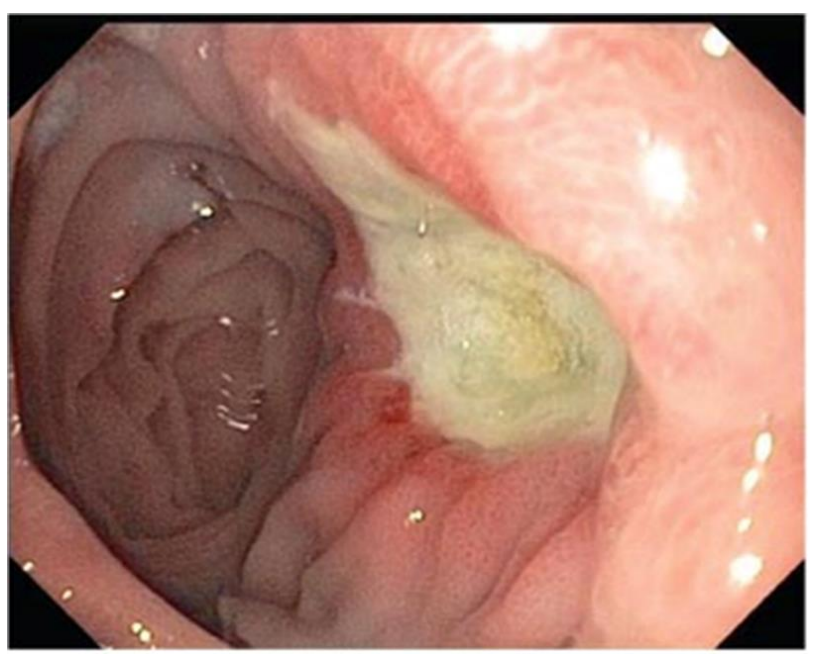

Figure 4. Ulceration in the gastric stump cinoma of the gastric stump was found in 2 cases $(2.98 \%)$ out of the total number of examinees (Figure 5). During a proximal endoscopic examination, changes in the gastroenteroanastomosis could be seen (Graph 2).

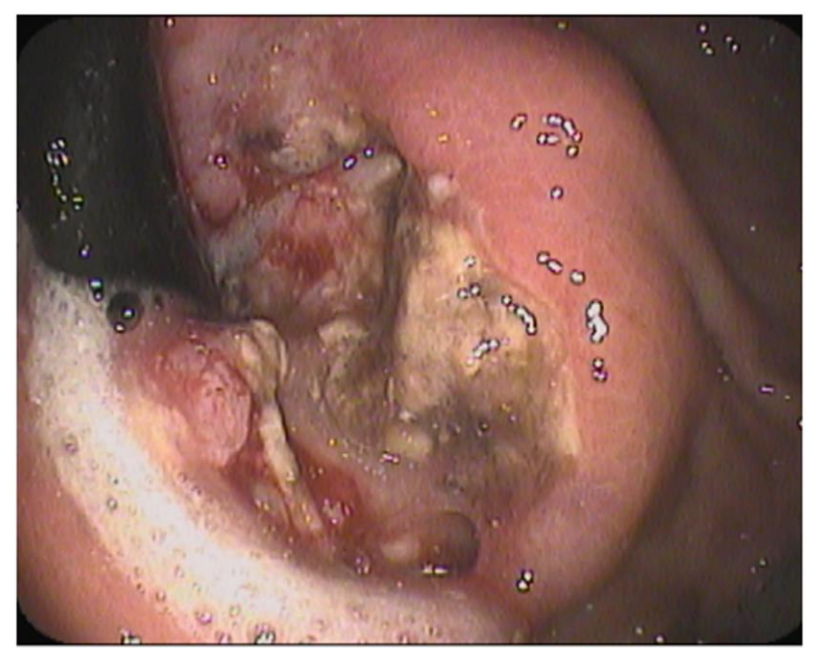

Figure 5. Carcinoma in the gastric stump 


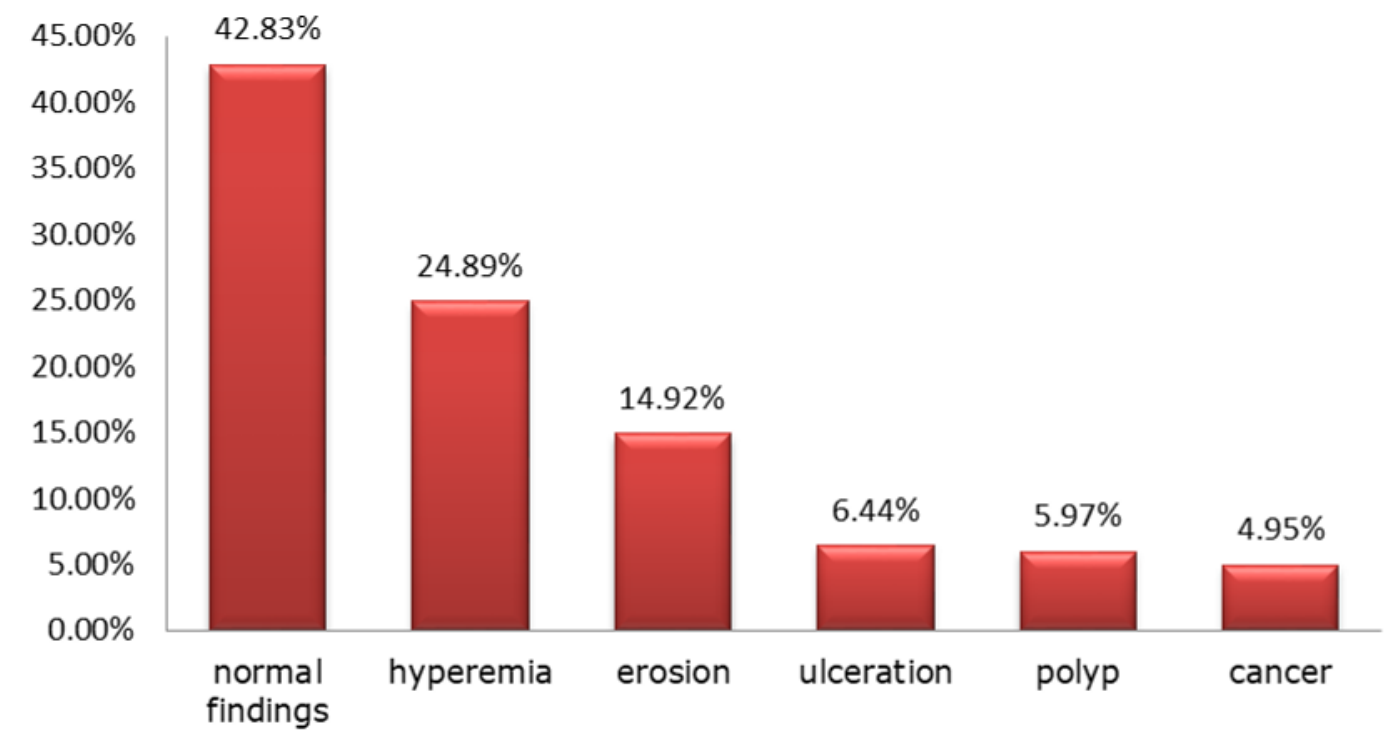

Graph 2. Endoscopic findings in gastroenteroanastomosis

Carcinoma of the gastroenteroanastomosis was found in $4.95 \%$ out of the total number of examinees. In both patient groups, regardless of the type of resection, morphological transformation of the gastric folds was present in the immediate vicinity of gastroenteroanastomosis (Figure 6).

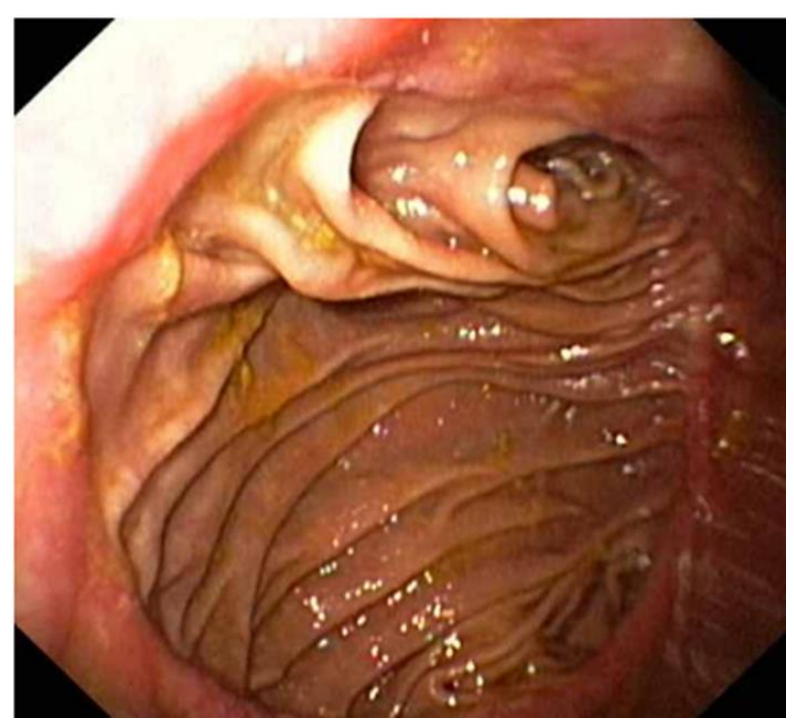

Figure 6. Transformation of gastric folds in the vicinity of gastroenteroanastomosis

\section{Discussion}

Partial resection is one of the surgical methods of choice in the treatment of recurrent ulcers of the stomach or duodenal bulb and their respective complications. Recurrent gastric or duodenal ulcers have become a rare clinical entity as the consequence of ever increasing availability of drugs for long-term reduction of stomach acid and nowadays common consideration of Helicobacter pylori infection and expanding possibilities of its eradication. Furthermore, in clinical practice, the awareness has considerably grown of the significance of gastroprotection when the use of NSAIDs is concerned (as well as with other drugs which increase the risk for ulcer disease).

The decision about the type of reconstruction (Billroth I or Billroth II) during gastroresection is made by the surgeon. In our examinees, Billroth II resections were more common, but the difference was without statistical significance. In the study by Vera et al. Billroth I gastric resections were statistically significantly more frequently performed (52.6\%) than Billroth II surgeries (7).

The study aimed to evaluate which type of resection was a better surgical treatment for gastric ulcer favored Billroth I resection over Billroth II. The results indicated better prognosis in the patients who underwent Billroth I resection, while quality of life was comparable in both groups of examinees.

Analyzing the factor of gender, we found that men were more commonly affected, as expected, since statistical information indicated that peptic ulcer disease was more prevalent in men compared to women. In $58.2 \%$ of patients, resections of the stomach were done for recurrent ulcer or its complications, and in $41.8 \%$ for ulcer at the duodenal bulb or its complications. The obtained results agreed well with the results obtained in other studies (8-10).

In normal conditions, endoscopic examination can be performed even as early as seven days after the resection. Esophagogastroduodenoscopy of the resected stomach is associated with some specific elements and difficulties compared to the examination of an unresected stomach. Post-resection morphology of the gastric stump varies considerably depending on the surgical approach employed and dimensions of the remnant stomach. In more extensive resections and with short gastric stumps, the 
insufflated air can escape through the stoma into the bowels, the endoscope is leaned onto the mucosa and a clear field of vision is more difficult to obtain. Further, respiratory movements are transferred via the diaphragm to the gastric stump, which also may disturb the inspection of the targeted portion of the stump. Moreover, occasional reflux from the afferent limb may splush the anastomosis and stump mucosa and disrupt the examination. Nevertheless, in most of the cases a clear field of vision can be obtained and an adequate endoscopic examination can be performed.

In most of our examinees endoscopic findings in the gastric stump were in order. Bilio-gastric refluxate was confirmed in $25.49 \%$ of all our patients, which was a lower proportion than that in other similar studies, where the percentage ranged from $60 \%$ to $90 \%$ (7).

The average age of our examinees with reflux $(64.07 \pm 7.45)$ was higher compared to the examinees without bilio-gastric reflux. These findings agree with the observations in a study by Vera et al. in 2005. Some authors believe that bilio-gastric reflux is more common in older examinees as the consequence of a higher prevalence of partial gastric resection in older populations (7). In our study, we found that duodenogastric reflux was more common after Billroth II resection, especially when the intervention was undertaken for gastric ulcer or its complications. Duodenogastric reflux was more often seen in patients with longer postoperative period of time. The average time from the surgery to endoscopically confirmed reflux was 16.91 years, approximating the results of Vera et al. (7). Several clinical and experimental studies have shown that bile acids and pancreatic proteolytic enzymes can damage gastric mucosa, and reflux of bile and duodenal contents also has a possible pathogenetic role in gastritis, gastric ulcer, chronic gastritis, reflux esophagitis, and esophageal and gastric cancer (11, 12). The exact mechanisms of gastric mucosal damage caused by duodenogastric reflux are still unknown. Duodenogastric reflux is probably an independent etiological factor and might play a synergistic role in the pathogenesis of gastric mucosal lesions along with gastric acid and Helicobacter pylori infection (12). Bechi et al. established in their study that with Billroth II resections the reflux was more abundant and concentrated. These authors recommended that in gastric ulcer or its complications partial gastrectomy with Billroth I reconstruction should be done. The principal endoscopic signs in patients with duodenogastric reflux are erythema of the gastric mucosa, presence of bile in the stomach, altered gastric folds and erosions $(13,14)$.

In the period of 24 hours, around $800 \mathrm{ml}$ of bile and around $1000 \mathrm{ml}$ of pancreatic juice flow into the stomach via the afferent limb. A scanty and occasional reflux indicates a small amount of bile that splashes only the edges of the anastomosis. A medium or moderately abundant reflux is characterized by a larger amount of bile splashing the anastomosis or its immediate vicinity. An abundant reflux denotes a large amount of bile splashing a broad area of gastric mucosa and accumulating in the gastric grooves $(2,15)$. The presence of duode- nogastric reflux depends as well on the type of resection (16).

In our study, ulcers were confirmed in 7 examinees $(10.44 \%)$ in the gastric stump, and in 4 cases $(6.44 \%)$ at the site of anastomosis. In the literature, the prevalence of ulcer recurrence is around $3 \%$. It most commonly occurs within two years of surgery. Bleeding and perforation are here more common than with primary ulcers. Recurrences are more common after surgery for duo denal than for gastric ulcers. They are most commonly the consequence if an inadequate surgical intervention, failing to suppress sufficiently the acidosecretory activity of the gastric juice. Recurrences are usually situated immediately below the suture line at the anastomosis site, while they are extremely rare in the gastric stump. One of the causes of ulcer recurrence is Zollinger-Ellison syndrome (ZES), with its ulcer diathesis due to gastrinomas. Since they are prone to complications, ulcer recurrences represent an absolute indication for surgical intervention, excluding in that regard Zollinger-Ellison syndrome, since it requires a different therapeutic approach (gastrinoma removal). For ulcer recurrences a resection (reduction of the acidosecretory area) or vagotomy should be performed $(2,4)$.

The results of our study indicate that carcinoma of the gastric stump is more common after resection for bulbar ulcer complications. Most authors attach importance to the period of time that has elapsed since the surgery and age of the patient at the time of surgical intervention $(17,18)$.

Studies have shown that in $22 \%$ of patients subjected to surgery carcinoma of the stomach occurs within 26-30 years of surgery, while in 1.9$4.7 \%$ it occurs within $5-15$ years of surgery. If the prevalence of carcinoma after resection is compared with that after medicamentous treatment of ulcer disease, a higher prevalence in the latter group has created the suspicion whether gastric resection may in fact have a protective effect $(4,17)$.

Histopathological preoperative finding and patient age at the time of surgery have an impact on the time of possible development of carcinoma of the resected stomach. Various studies have demonstrated that carcinoma of the stomach, after a longer time interval after the resection, is eight times more common in the gastric stump in comparison to control examinees with intact stomach. The same authors found that the period of time after the surgery, patient age at the time of surgery and histological changes in the stomach before the surgery had an impact on the occurrence of this carcinoma $(7,9)$. The postoperative interval is the most important determinant of cancer risk following gastrectomy (19). In the study by Vera et al. Carcinomas were diagnosed in $2.24 \%$ of examinees (7). Carcinoma of the gastric stump was most frequently situated at the site of anastomosis, in the vicinity of the afferent limb, in the stump and cardia. The disease prognosis in patients with carcinoma of the gastric stump is worse than that in patients with primary gastric carcinoma. The treatment is exclusively surgical, with subsequent oncological therapy. The prevention of carcinoma of the gastric stump consists of regular endoscopic and histologic controls 
of the surgically treated patients, following the surveillance protocol for precancerous conditions $(2,4)$.

In our study, various changes at the site of anastomosis were seen as well, differing depending on the type of performed resection. In the case of gastrojejunal anastomosis, the stoma was wide and the delineation between afferent and efferent limbs was not conspicuous. The inflammation process almost regularly involved the gastric mucosa at the site of anastomosis. The process of inflammation very rarely represented localized anastomositis, and was often a part of the general inflammatory process involving the whole gastric stump mucosa. In some cases the mucosa of the anastomosis was inflamed as a whole, shiny, and red as if lacquered. At such a changed anastomosis, erosions and ulcerations can be seen in varying numbers, and contact bleedings are not rare as well due to increased fragility of the inflamed mucosa $(2,15)$.

In patients resected by Billroth II method, the gastric stump opens into a so called 'anastomotic chamber', created by the jejunal lumen more or less dilated as the consequence of surgical juncture with the stomach. In this 'anastomotic chamber' openings of the afferent and efferent limbs can be seen. Folds of the afferent limb mucosa are circular and mucosa is light pink in color. The inflammation is characterized by redness, fold alterations, and occasional presence of erosions and ulcerations. A peptic ulcer in the afferent limb is a rare finding. It is sometimes very difficult or even impossible to enter the afferent limb. Endoscopic examination of the efferent limb reveals the jejunal mucosa with circular folds and characteristic color, different than the color of gastric mucosa. In the immediate vicinity of the anastomosis, mucosa of the efferent limb is pink red, with thickened or thin and divergent sometimes unconspicuous folds.

\section{Conclusion}

After gastric resection and reconstruction by Billroth I or II method in around half of the patients endoscopic changes in the remnant stomach are present. Ulcerations in the gastric stump or at the anastomosis site are more common in patients with Billroth II resection. Further, bilio-gastric refluxate is more common after Billroth II resection, especially in those with longer postoperative period of time. Although in our clinical practice it is increasingly rare to encounter the patients with resected stomach, we should not overlook the possibility of damage to the remnant of the stomach. This especially relates to an increased risk of carcinoma developing in the gastric stump after a period of time after the resection. In that regard, timely preventive endoscopic control examinations should be introduced.

References

1. Pulimood BM, Knudsen A, Coghill NF. Gastric mucosa after partial gastrectomy. Gut 1976; 17:463-70. [CrossRef] [PubMed]

2. Vucelić B. Ulkusna bolest. In: Gastroenterologija i hepatologija. Zagreb: Medicinska naklada; 2002. p. 480-500.

3. Laušević D, Peško PM, Krstic SN, Sijacki A, Gvozdenović MS, Bumbasirević V, et al. Perspektive hirurškog lečenja krvarećeg peptičkog ulkusa. Acta Chir Iugosl 2007; 54(1):157-64. [PubMed]
4. Yamada T, Alpers DH, Kalloo AN, Kaplowitz N, Owyang C, Powell DW. Textbook of gastroenterology. 5th ed. Hoboken (NJ): Wiley-Blackwell; 2009.

[CrossRef] [PubMed]

5. Greene FL. Neoplastic changes in the stomach after gastrectomy. Surg Gynecol Obstet 1990; 171(6):47780. [PubMed]

6. R Core Team. R: A Language and Environment for Statistical Computing. R Foundation for Statistical 
Computing, Vienna, Austria, 2014. Available at: http://www.R-project.org/. Accessed March 3, 2015.

7. Vere CC, Cazacu S, Comănescu V, Mogoantă L, Rogoveanu I, Ciurea T. Endoscopical and histological features in bile reflux gastritis. Rom J Morphol Embryol 2005; 46(4):269-74. [PubMed]

8. Pulimood BM, Knudsen A, Coghill NF. Gastric mucosa after partial gastrectomy. Gut 1976; 17:463-70. [CrossRef] [PubMed]

9. Lin JK, Hu PJ, Li CJ, Zeng ZR, Zhang XG. A study of diagnosis of primary biliary reflux gastritis, Zhonghua Nei Ke Za Zhi 2003; 42(2):81-83. [PubMed]

10. Fukuhara K, Osugi $H$, Takada N, Takemura M, Lee S, Taguchi S, et al. Correlation between duodenogastric reflux and remnant gastritis after distal gastrectomy. Hepatogastroenterol 2004; 51(58):1241-4. [PubMed]

11. Lee Y, Tokunaga A, Tajiri T, Masuda G, Okuda T, Fujita $\mathrm{I}$, et al. Inflammation of the gastric remnant after gastrectomy: mucosal erythema is associated with bile reflux and inflammatory cellular infiltration is associated with Helicobacter pylori infection. J Gastroenterol 2004; 39(6):520-6. [CrossRef] [PubMed]

12. Ma M, Chen J, Zhang YY, Li ZY, Jiang MZ, Yu JD. Pathogenic effects of primary duodenogastric reflux on gastric mucosa of children. Zhonghua $\mathrm{Er} \mathrm{Ke} \mathrm{Za} \mathrm{Zhi.}$ 2008; 46(4):257-62. [PubMed]
13. Bechi $P$, Amorosi A, Mazzanti R, Romagnoli $P$, Tonelli $L$. Gastric histology and fasting bile reflux after partial gastrectomy. Gastroenterology 1987; 93(2):335-43. [CrossRef] [PubMed]

14. Tan SY, Davis JD, Davis CA. Theodor Billroth (18291894): pioneer of modern surgery. Singapore Med J 2008; 49 (1):72-75.

15. Katičić M. Peptička ulkusna bolest. Medicus 2006; 15(1):39-52.

16. Zlatić A, Stojanović M, Mihailović D, RadovanovićDinić, Protić $M$, Veljković $R$. The role of duodenogastric reflux in formation of precarcinogenic gastric lesions: An experimental study. Med Pregl 2013; 66(7-8):28529. [CrossRef] [PubMed]

17. Whiting JL, Sigurdsson A, Rowlands DC, Hallissey MT, Fielding JW. The long term results of endoscopic surveillance of premalignant gastric lesions. Gut 2002; 50:378-81. [CrossRef] [PubMed]

18. Dinis-Ribeiro M, Lopes C, da Costa-Pereira A, Guilherme $M$, Barbosa J, Lomba-Viana $\mathrm{H}$, et al. A follow up model for patients with atrophic chronic gastritis and intestinal metaplasia. J Clin Pathol 2004; 57:177-82. [CrossRef] [PubMed]

19. Safatle-Ribeiro AV, Ribeiro Júnior $U$, Sakai $P$, Iriya $K$, Ishioka S, Gama-Rodrigues J. Gastric stump mucosa: is there a risk for carcinoma? Arq Gastroenterol 2001; 38(4):227-31. [CrossRef] [PubMed] 


\title{
ENDOSKOPSKE PROMENE SLUZNICE ŽELUDAČNOG PATRLJKA NAKON HIRUŠKE TERAPIJE ULKUSNE BOLESTI
}

\author{
Biljana Radovanović-Dinić1,2, Snežana Tešić-Rajković1,2
}

\author{
${ }^{1}$ Univerzitet u Nišu, Medicinski fakultet, Niš, Srbija \\ ${ }^{2}$ Klinički centar Niš, Klinika za gastroenterologiju i hepatologiju, Niš, Srbija
}

Kontakt: Biljana Radovanović-Dinić

Elektronska 1/1, 18000 Niš, Srbija

E-mail: bikius@yahoo.com

Danas je hirurška terapija uglavnom rezervisana samo za bolesnike s komplikacijama ulkusne bolesti ili one malobrojne bolesnike čiji su ulkusi refrakterni na konvencionalnu terapiju. Dvotrećinska resekcija želuca je jedna od hiruških intervencija u hirurškom tretmanu ulkusne bolesti. Naša prospektivna studija analizirala je 67 bolesnika sa dvotrećinskom resekcijom želuca i rekonstrukcijom po metodi Billroth I ili Billroth II. Kod svih ispitanika uradjena je proksimalna endoskopija. Tokom endoskopije opservirani su jednjak, želudačni patrljak, anastomoza i priključne vijuge. Prednost muškaraca je bila izraženija u grupi bolesnika sa Billroth I resekcijom $\left(\chi^{2}=1,90 ; p=0,1676\right)$. Prosečno starosno doba ispitanika bila je 64,27 $\pm 10,07$ godina. Kod $39(58,21 \%)$ bolesnika uzrok resekcije je bio ulkus želuca ili komplikacije istog, a kod $28(41.79 \%)$ ulkus bulbusa duodenuma ili komplikacije istog $\left(\chi^{2}=8,75 ; p=\right.$ 0,0678 ). Kod bolesnika sa ulkusom želuca statistički značajno češće je urađena resekcija želuca po metodi Billroth II $(p<0,05)$. Prosečno vreme od resekcije do nalaza je nešto duže kod bolesnika sa resekcijom po metodi Billroth I (vrednost $\mathrm{p}$ bliska nivou značajnosti od 0,05 ). Duodenogastrični refluks je češće verifikovan kod bolesnika sa resekovanim želucem po metodi Billroth II $\left(\chi^{2}=8,75 ; p=0,0678\right)$. Ulceracija u želudačnom patrljku je bila prisutna kod 7 $(10.44 \%)$ ispitanika. Karcinom je bio prisutan kod dva pacijenta $(2,98 \%)$ u želudačnom patrljku, odnosno kod tri $(4,95 \%)$ na anastomozi. I pored toga što se u kliničkoj praksi sve ređe susrećemo sa bolesnicima koji imaju resekovan želudac, nikako ne treba izgubiti iz vida mogućnost nastanka oštećenja preostalog dela želuca.

Acta Medica Medianae 2018;57(4):101-109.

Ključne reči: želudačni patrljak, endoskopija, ulkus želuca 